\title{
Nocardiopsis tropica sp. nov., Nocardiopsis trehalosi sp. nov., nom. rev. and Nocardiopsis dassonvillei subsp. albirubida subsp. nov., comb. nov.
}

\author{
Lyudmila I. Evtushenko, ${ }^{1}$ Victoria V. Taran, ${ }^{1}$ Vladimir N. Akimov, ${ }^{1}$ \\ Reiner M. Kroppenstedt, ${ }^{2}$ James M. Tiedje ${ }^{3}$ and Erko Stackebrandt ${ }^{2}$
}

1 All-Russian Collection of Microorganisms (VKM), Institute of Biochemistry and Physiology of Microorganisms, Russian Academy of Sciences, Pushchino, Moscow Region, 142292, Russia

2 German Collection of Microorganisms and Cell Cultures, D-38124 Braunschweig, Germany

3 Center for Microbial Ecology, Michigan State University, East Lansing, MI 55556, USA

\author{
Author for correspondence: Lyudmila I. Evtushenko. Tel: +7 0959257448 . Fax : + 70959233602. \\ e-mail: evtushenko@ibpm.serpukhov.su
}

\begin{abstract}
Sixteen strains isolated from different soils and marine sediments and ' Nocardiopsis trehalosi' VKM Ac-942 ${ }^{\top}$ were subjected to taxonomic analyses. The morphological and chemotaxonomic characteristics of the strains matched those described for members of the Nocardiopsis. Based on 165 rDNA sequence analysis, DNA-DNA hybridization values and phenotypic characteristics, including the composition of menaquinones and cell wall teichoic acids, two new species are proposed, Nocardiopsis tropica sp. nov. (type strain VKM Ac1457') and Nocardiopsis trehalosi sp. nov., nom. rev. (type strain VKM AC-942 $^{\top}$ $=$ JCM $3357^{\top}=$ NRRL 12026'). Nocardiopsis dassonvillei VKM AC-1882 ${ }^{\top}$ (formerly Nocardiopsis albirubida) differs from other strains of this species by the presence of MK-10 as the major menaquinone, cell wall teichoic acid structure, and numerical analysis based on $\mathbf{1 1 5}$ growth and physiological characteristics. The strain is reclassified as the subspecies Nocardiopsis dassonvillei subsp.

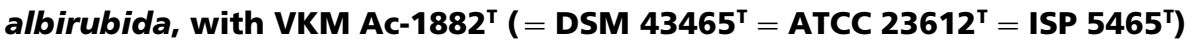
designated the type.
\end{abstract}

Keywords: Nocardiopsis dassonvillei subsp. albirubida, Nocardiopsis trehalosi, Nocardiopsis tropica, 16S rDNA, DNA-DNA relatedness

\section{INTRODUCTION}

The genus Nocardiopsis was described by Meyer (1976) to comprise actinomycetes with fragmenting mycelium and a cell wall containing meso-diaminopimelic acid and no diagnostically important carbohydrates. However, strains assigned to the genus on the basis of the above characteristics were shown to be heterogeneous in composition of lipids (Goodfellow et al., 1988; Grund \& Kroppenstedt, 1990). Consequently, the genus Nocardiopsis was proposed to include only organisms with the following salient chemotaxonomic characteristics: cell wall chemotype III C (meso isomer of diaminopimelic acid and no characteristic sugars in whole-cell hydrolysates) (Lechevalier \& Lechevalier, 1970), phospholipid type PIII (phosphatidylcholine

The GenBank/EMBL accession numbers for the 16S rDNA sequences of Nocardiopsis tropica VKM Ac- $1457^{\top}$ and Nocardiopsis trehalosi VKM Ac-942 ${ }^{\top}$ are AF105971 and AF105972, respectively. and phosphatidylmethylethanolamine as characteristic phospholipids) (Lechevalier et al., 1977), menaquinone MK-10 with variable degrees of saturation as the major isoprenoid quinones (Collins et al., 1977), fatty acids of the $3 \mathrm{~d}$ type according to the classification of Kroppenstedt (1985) and a DNA G + C content ranging between 64 and $71 \mathrm{~mol} \%$ (Grund \& Kroppenstedt, 1990). This grouping was confirmed by $16 \mathrm{~S}$ rDNA sequence analysis (Rainey et al., 1996). The current genus Nocardiopsis contains seven species: Nocardiopsis dassonvillei (Meyer, 1976), Nocardiopsis alba, Nocardiopsis listeri (Grund \& Kroppenstedt, 1990), Nocardiopsis halophila (Al-Tai \& Ruan, 1994), Nocardiopsis lucentensis (Yassin et al., 1993), Nocardiopsis prasina and Nocardiopsis synnemataformans (Yassin et al., 1997). With the exception of $N$. halophila, species affiliation was supported by DNADNA reassociation data and $16 \mathrm{~S}$ rDNA sequence analysis (Fischer et al., 1983; Rainey et al., 1996; Yassin et al., 1997).

At the phenetic level, the differentiation of Nocardiop- 
sis species is based on the colour of the aerial and vegetative mycelium, diffusible pigments, menaquinone composition and physiological characteristics, including halotolerance and growth at different $\mathrm{pH}$ values (Grund \& Kroppenstedt, 1990; Kroppenstedt, 1992; Al-Tai \& Ruan, 1994; Miyashita et al., 1984; Yassin et al., 1997). Data on the cell wall teichoic acids of Nocardiopsis spp. show that the structure and composition of these polymers can be chemical markers of Nocardiopsis species (Streshinskaya et al., 1998; Tul'skaya et al., 1993, 1995a).

In this paper we present the results of a taxonomic study of 17 strains isolated from different sources and identified as members of the genus Nocardiopsis, including 'Nocardiopsis trehalosi' VKM Ac-942 (Dolak et al., 1981). Based on the presenting data, we propose two new species, Nocardiopsis tropica sp. nov. and Nocardiopsis trehalosi sp. nov., nom. rev., and the new combination Nocardiopsis dassonvillei subsp. albirubida subsp. nov., comb. nov.

\section{METHODS}

Organisms and their sources. The strains studied and their sources are given in Table 1. The new strains were isolated on the QMod media used for Frankia sp. (Blom et al., 1980), oatmeal agar (ISP medium 3) (Shirling \& Gottlieb, 1966) and peptone-yeast extract agar $(5 \mathrm{~g}$ peptone, $3 \mathrm{~g}$ yeast extract, $5 \mathrm{~g}$ glucose, $0 \cdot 2 \mathrm{~g} \mathrm{H}_{2} \mathrm{PO}_{4}, 11$ distilled water, $15 \mathrm{~g}$ agar, pH 7.4) (Naumova et al., 1980).

Pigmentation and morphology. Strains were grown at $28^{\circ} \mathrm{C}$ on various ISP media or other diagnostic media (Shirling \& Gottlieb, 1966; Gause et al., 1983). Pigmentation and morphology were observed after $14 \mathrm{~d}$ growth. Phasecontrast microscopy and transmission electron microscopy (model JEM-7 microscope) were used to study morphological characteristics and spore surfaces.

Chemotaxonomy. Freeze-dried cells used for chemical analysis were obtained from cultures grown on liquid peptoneyeast extract broth on a rotary shaker at $28^{\circ} \mathrm{C}$ for $2-3 \mathrm{~d}$. The isomer of diaminopimelic acid was determined by the method of Becker et al. (1964). Sugars in whole-cell hydrolysates $\left(1 \mathrm{M} \mathrm{HCl}, 105^{\circ} \mathrm{C}, 30 \mathrm{~min}\right)$ were analysed by TLC as described by Hasegawa et al. (1983). Mycolic acids and phospholipids were examined using the methods of Minnikin et al. $(1975,1984)$. Menaquinones were extracted and purified as described by Collins et al. (1977), and their composition was determined using a model MAT 8430 mass spectrometer (Finnigan). For GLC analysis of fatty acids, cultures were grown in Trypticase-Soy broth (BBL Microbiology Systems) for $2 \mathrm{~d}$. Cells were harvested by centrifugation and about $40 \mathrm{mg}$ (w/w) of the cells was saponified, methylated, extracted and analysed using the Microbial Identification System described by Miller (1982).

Physiology. Assimilation of carbon sources at a final concentration of $1 \%(\mathrm{w} / \mathrm{v})$ was tested using ISP 9 as the basal medium (Shirling \& Gottlieb, 1966). The ability to grow on methanol, ethanol, propanol and butanol as sole carbon sources was examined by using the carbon-free medium of Stevenson (1967). Utilization of nitrogen sources, sulphide production and degradation of aesculin, arbutin, pectin and Tweens was determined as described by Williams et al. (1983). Decomposition of other organic compounds, utilization of organic acids, production of acids from carbohydrates, urease and allontainase, and nitrate reduction were studied as described previously (Gordon, 1967; Gordon \& Mihm, 1957). The effect of inhibitors and temperature on growth was determined using peptone-yeast extract agar as the basal medium. Growth in the presence of salt at different concentrations was examined using Bennett agar as described by Al-Tai \& Ruan (1994).

Numerical analysis. Phenotypic similarities were calculated using the simple matching coefficient and Jaccard's coefficient. The BIOMATRIX software was used for cluster analysis (Ozerskaya \& Vasilenko, 1992).

DNA isolation and DNA-DNA hybridization study. Total DNA was isolated by the technique of Bradley et al. (1973). $\left[{ }^{3} \mathrm{H}\right] \mathrm{DNAs}$ from reference strains were obtained by in vitro nick translation. The procedure used for hybridization experiments (membrane filter method) was described by Meyer \& Schleifer (1978) and Stackebrandt et al. (1981). The reassociation temperature was $25^{\circ} \mathrm{C}$ below the thermal denaturation midpoint of the reference DNA.

16S rDNA sequence determination. The $16 \mathrm{~S}$ rRNA gene was amplified by using the PCR method and prokaryotic $16 \mathrm{~S}$ rDNA universal primers fD1 and $\mathrm{rP1}$ as described by Weisburg et al. (1991) and Zhou et al. (1997). The samples were subjected to an initial denaturating step consisting of 3 min at $98^{\circ} \mathrm{C}$. The PCR program used was as in Rainey et al. (1996). The sequences of $16 \mathrm{~S}$ rDNA were analysed directly using the purified PCR products as the sequencing template. The sequencing reactions were performed with automated fluorescent Taq cycle sequencing using the ABI Catalyst 800 and a model ABI 373A automatic DNA Sequencer (Applied Biosystems), according to the manufacturer's protocol.

Phylogenetic analysis. The $16 \mathrm{~S}$ rDNA sequences of $\mathrm{No}$ cardiopsis strains were initially aligned with those of type species of the class Actinobacteria (Stackebrandt et al., 1997) and subsequently with members of the family Nocardiopsaceae (Rainey et al., 1996) using the ae2 editor (Maidak et al., 1997). Evolutionary distances were calculated by the method of Jukes \& Cantor (1969). Phylogenetic dendrograms (DeSoete, 1983) were constructed using sequences from different sets of reference strains. Bootstrap analysis was used to evaluate the tree topology of the neighbourjoining data by performing 1000 resamplings (Felsenstein, 1985).

Nucleotide sequence accession numbers. The GenBank accession numbers of the 16S rRNA gene sequences of strains Nocardiopsis sp. VKM Ac- $1457^{\mathrm{T}}$ and ' $N$. trehalosi' VKM Ac-942 determined in this study are AF105971 and AF105972, respectively. These sequences were compared with the following published sequences from EMBL: N. alba DSM 43377 , X97883; N. dassonvillei DSM 43111 ${ }^{\mathrm{T}}$, X97886; N. dassonvillei DSM 43884, X97885; N. dassonvillei DSM 40465, X97882; $N$. listeri DSM 40297" , X97887; $N$. lucentensis DSM 44048 ${ }^{\mathrm{T}}$, X97888; N. prasina DSM 43845 ${ }^{\mathrm{T}}$, X97884; N. synnemataformans DSM 44143 ${ }^{\mathrm{T}}$, X99593; Actinomadura madurae DSM 43067 , X97889; Microtetraspora glauca DSM $43311^{\mathrm{T}}$, X97891. 
Table 1. List of Nocardiopsis strains used in this study and their sources

\begin{tabular}{|c|c|c|c|}
\hline Species & Strain & $\begin{array}{l}\text { Other designation of strain or } \\
\text { source of new isolate }\end{array}$ & Reference \\
\hline N. alba & VKM Ac- $1883^{\mathrm{T}}$ & DSM $43377^{\mathrm{T}}, \mathrm{JCM} 9419^{\mathrm{T}}$, IFO $15097^{\mathrm{T}}$ & $\begin{array}{l}\text { Lechevalier \& Lechevalier (1970); Grund \& } \\
\text { Kroppenstedt (1990) }\end{array}$ \\
\hline N. alba & VKM Ac-1879 & DSM 43120, IMRU 1572 & Grund \& Kroppenstedt (1990) \\
\hline N. alba & VKM Ac-1884 & DSM 43378, IMRU 714, Goodfellow A119 & $\begin{array}{l}\text { Gordon \& Horan (1968); Grund \& } \\
\text { Kroppenstedt (1990) }\end{array}$ \\
\hline N. dassonvillei & VKM Ac- $797^{\mathrm{T}}$ & DSM $43111^{\mathrm{T}}$, ATCC $23918^{\mathrm{T}}$, IMRU $509^{\mathrm{T}}$ & $\begin{array}{l}\text { Lechevalier \& Lechevalier (1970); Meyer } \\
\text { (1976) }\end{array}$ \\
\hline N. dassonvillei & VKM Ac-773 & DSM 43235, ATCC 23219, IMRU 1250 & $\begin{array}{l}\text { Lechevalier \& Lechevalier (1970); Meyer } \\
\text { (1976) }\end{array}$ \\
\hline N. dassonvillei & VKM Ac- 836 & DSM 43884, ATCC 43517, JCM 6843 & Abyzov et al. (1983); Yassin et al. (1997) \\
\hline N. dassonvillei & VKM Ac- $1882^{\mathrm{T}}$ & DSM $40465^{\mathrm{T}}$, ATCC $23612^{\mathrm{T}}$, ISP $5465^{\mathrm{T}}$ & Kudrina (1957); Yassin et al. (1997) \\
\hline$N$. listeri & VKM Ac- $1881^{\mathrm{T}}$ & DSM $40297^{\mathrm{T}}$, ATCC $27442^{\mathrm{T}}$, ISP $5297^{\mathrm{T}}$ & $\begin{array}{l}\text { Erikson (1935); Grund \& Kroppenstedt } \\
\text { (1990) }\end{array}$ \\
\hline$N$. lucentensis & VKM Ac- $1962^{\mathrm{T}}$ & DSM $44048^{\mathrm{T}}$, ATCC $51300^{\mathrm{T}}, \mathrm{JCM} 9420^{\mathrm{T}}$ & Yassin et al. (1993) \\
\hline N. prasina & VKM Ac- $1880^{\mathrm{T}}$ & DSM $43845^{\mathrm{T}}, \mathrm{JCM} 3336^{\mathrm{T}}$, IFO $14423^{\mathrm{T}}$ & Miyashita et al. (1984); Yassin et al. (1997) \\
\hline 'N. trehalosi' & VKM Ac-942 & IFO $14201^{\mathrm{T}}, \mathrm{JCM} 3357^{\mathrm{T}}, \mathrm{NRRL} 12026^{\mathrm{T}}$ & Dolak et al. (1981) \\
\hline \multicolumn{4}{|l|}{ Nocardiopsis spp. } \\
\hline & VKM Ac-1176 & Arctic soil, Russia & This study \\
\hline & VKM Ac-1453 & Intestinal tract of Goloturia sp. & This study \\
\hline & VKM Ac-1455 & Rhizosphere of Casuarina sp., Seychelles & This study \\
\hline & VKM Ac-1456 & Rhizosphere of Casuarina sp., Seychelles & This study \\
\hline & VKM Ac- $1457^{\mathrm{T}}$ & Rhizosphere of Casuarina sp., Seychelles & This study \\
\hline & VKM Ac-1458 & Rhizosphere of Casuarina sp., Seychelles & This study \\
\hline & VKM Ac-1459 & Rhizosphere of Casuarina sp., Seychelles & This study \\
\hline & VKM Ac- 1460 & Rhizosphere of Casuarina sp., Seychelles & This study \\
\hline & VKM Ac-1485 & Soil, Seychelles & This study \\
\hline & VKM Ac-1486 & Soil, Seychelles & This study \\
\hline & VKM Ac-1487 & Rhizosphere of Casuarina sp., Seychelles & This study \\
\hline & VKM Ac-1490 & Rhizosphere of Casuarina sp., Seychelles & This study \\
\hline & VKM Ac-1498 & Rhizosphere of Casuarina sp., Seychelles & This study \\
\hline & VKM Ac-1751 & No data & This study \\
\hline & VKM Ac-1758 & Polluted soil, Russia & This study \\
\hline & VKM Ac-1759 & No data & This study \\
\hline
\end{tabular}

\section{RESULTS AND DISCUSSION}

\section{Pigmentation and morphological characteristics}

The aerial mycelium formed by most isolates was white to off white, while the vegetative mycelium was yellow-brown or colourless. Strain VKM Ac- $1457^{\mathrm{T}}$ differed from the other strains in this study by the formation of ochra-red to orange vegetative mycelium pigments on oatmeal and Czapek's agars and formation of yellow to orange-yellow diffusible pigments on oatmeal and glycerol-nitrate agars. Distinguishable substrate mycelial pigments were reported previously in N. synnemataformans (pimento colour) (Yassin et al., 1997), N. halophila (coral-red to red) (Al-Tai \& Ruan, 1994) and N. dassonvillei DSM 40465 (brownishred or yellow-orange) (Grund \& Kroppenstedt, 1990; Kroppenstedt, 1992). All strains that exhibited aerial hyphae showed the typical zig-zag fragmentation and formation of smooth, elongated spores of irregular size. Aerial hyphae were not observed in $N$. listeri
VKM Ac- $1881^{\mathrm{T}}$ and $N$. alba VKM Ac-1879. Morphological structures such as sunnemata (Yassin et al., 1997) were not discovered.

\section{Chemotaxonomic characteristics}

All strains contained the meso-isomer of diaminopimelic acid in their cell walls; diagnostic sugars were not observed. No mycolic acids were detected in wholecell methanolysates. Phospholipid pattern type PIII sensu Lechevalier et al. (1977) was determined in lipid extracts. The major menaquinone contained 10 isoprene subunits in the side chain with a variable degree of saturation; $\mathrm{MK}-10\left(\mathrm{H}_{4}\right), \mathrm{MK}-10\left(\mathrm{H}_{6}\right)$ or $\mathrm{MK}-10\left(\mathrm{H}_{2}\right)$ were predominant in different new isolates. In addition, different combinations of minor amounts of MK-9( $\left.\mathrm{H}_{2}\right)$, MK-9 $\left(\mathrm{H}_{4}\right)$, MK-9 $\left(\mathrm{H}_{6}\right), \mathrm{MK}-11\left(\mathrm{H}_{4}\right)$ or MK-8( $\left(\mathrm{H}_{2}\right)$ were observed in some strains. Nocardiopsis sp. VKM Ac- $1457^{\mathrm{T}}$ possessed MK-10 $\left(\mathrm{H}_{6}, \mathrm{H}_{8}\right)$, and ' $N$. trehalosi' VKM Ac- $942^{\mathrm{T}}$ contained mainly $\mathrm{MK}-10\left(\mathrm{H}_{4}\right.$, 
Table 2. Fatty acids of Nocardiopsis strains studied

\begin{tabular}{|c|c|c|c|c|c|c|c|c|c|c|c|c|}
\hline \multirow[t]{2}{*}{ Name } & \multirow[t]{2}{*}{ Strain } & \multicolumn{11}{|c|}{ Fatty acid composition ( $\%$ of total fatty acids) } \\
\hline & & 16:0 & 18:0 & i16:0 & i15:0 & i17:0 & ai15:0 & ai17:0 & $18 \mathrm{Me}$ & $16: 1$ & $17: 1$ & $18: 1$ \\
\hline N. dassonvillei & VKM Ac- $797^{\mathrm{T}}$ & $2 \cdot 2$ & $5 \cdot 8$ & $26 \cdot 7$ & $0 \cdot 8$ & $2 \cdot 1$ & $3 \cdot 2$ & $19 \cdot 8$ & $6 \cdot 4$ & $1 \cdot 2$ & $5 \cdot 2$ & $18 \cdot 3$ \\
\hline N. dassonvillei & VKM Ac-836 & 1.9 & $5 \cdot 5$ & $30 \cdot 2$ & $0 \cdot 5$ & $2 \cdot 6$ & $2 \cdot 2$ & $20 \cdot 3$ & $13 \cdot 5$ & $1 \cdot 6$ & $3 \cdot 3$ & $12 \cdot 5$ \\
\hline Nocardiopsis sp. & VKM Ac-1453 & $5 \cdot 9$ & $6 \cdot 6$ & $21 \cdot 8$ & $1 \cdot 0$ & $1 \cdot 4$ & $6 \cdot 6$ & $14 \cdot 0$ & $5 \cdot 3$ & $3 \cdot 4$ & $8 \cdot 6$ & $9 \cdot 2$ \\
\hline Nocardiopsis sp. & VKM Ac-1456 & $4 \cdot 3$ & $3 \cdot 9$ & $23 \cdot 9$ & $1 \cdot 1$ & $2 \cdot 2$ & $5 \cdot 4$ & $16 \cdot 7$ & $3 \cdot 4$ & $1 \cdot 3$ & $5 \cdot 2$ & $14 \cdot 3$ \\
\hline Nocardiopsis sp. & VKM Ac- $1457^{\mathrm{T}}$ & $4 \cdot 1$ & $5 \cdot 0$ & $23 \cdot 8$ & $1 \cdot 1$ & $1 \cdot 6$ & $6 \cdot 8$ & $15 \cdot 2$ & $4 \cdot 4$ & $1 \cdot 7$ & $6 \cdot 9$ & $18 \cdot 9$ \\
\hline Nocardiopsis sp. & VKM Ac-1459 & $6 \cdot 7$ & $7 \cdot 2$ & $24 \cdot 4$ & $1 \cdot 3$ & $1 \cdot 7$ & $6 \cdot 0$ & $16 \cdot 9$ & $5 \cdot 1$ & $3 \cdot 4$ & $3 \cdot 4$ & $13 \cdot 0$ \\
\hline Nocardiopsis sp. & VKM Ac-1490 & $3 \cdot 7$ & $7 \cdot 5$ & $28 \cdot 2$ & $0 \cdot 7$ & $1 \cdot 4$ & $3 \cdot 5$ & $15 \cdot 7$ & $4 \cdot 6$ & $1 \cdot 3$ & $5 \cdot 7$ & $7 \cdot 5$ \\
\hline
\end{tabular}

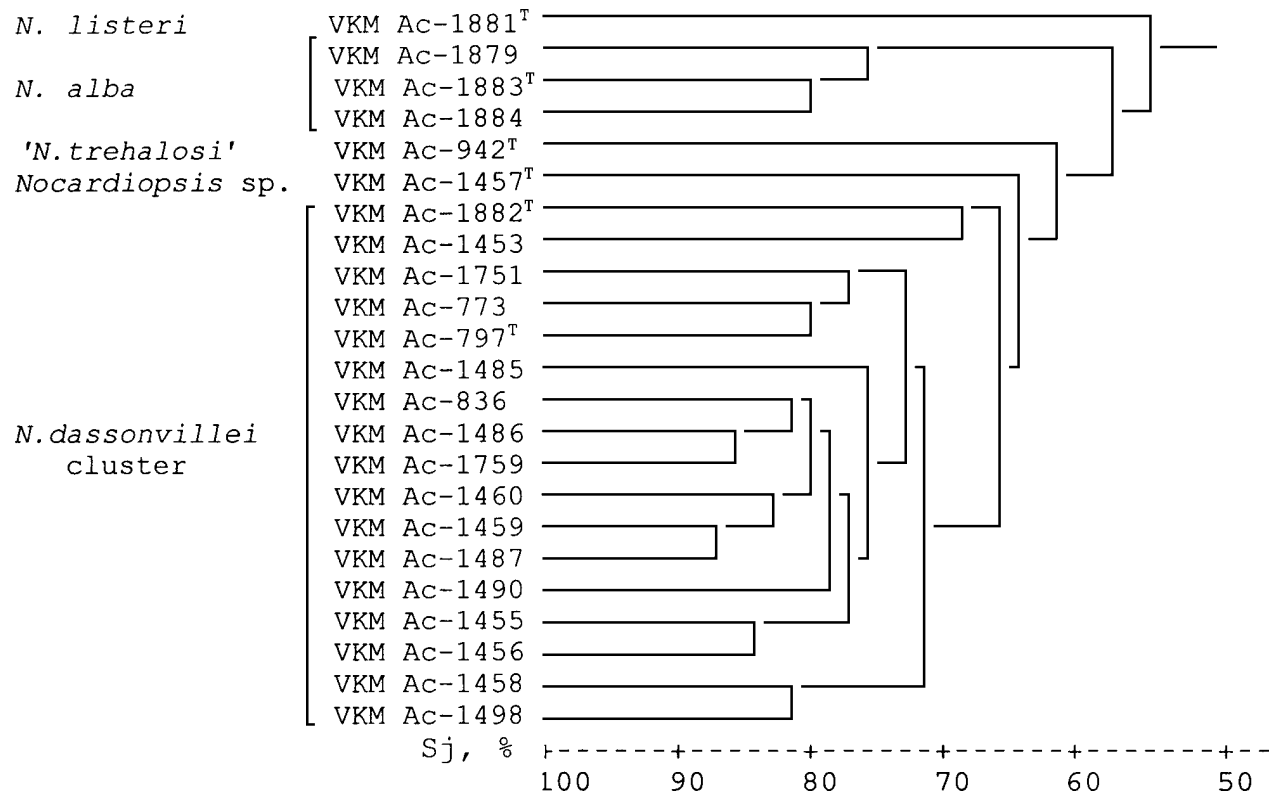

Fig. 1. Dendrogram showing the relationships among strains of the genus Nocardiopsis. The dendrogram is based on 115 growth and physiological characteristics and was drawn by using Jaccard's coefficient values (\%).

$\mathrm{H}_{6}$ ). Strain $N$. dassonvillei VKM Ac- $1882^{\mathrm{T}}$ (formerly N. alborubida) contained MK-10 as the major menaquinone; minor amounts of MK-10( $\left.\mathrm{H}_{2}\right)$ and MK-11 or MK-9 and MK-8 were also determined in various experiments. The fatty acid pattern of the strains under study was composed of mainly iso- and anteisobranched acids combined with tuberculostearic acid (Me18), straight chain saturated $(16: 0,18: 0)$ and unsaturated $(16: 1,17: 1,18: 1)$ acids (Table 2); no hydroxy fatty acids were detected. All these characteristics are typical of the genus Nocardiopsis (Grund \& Kroppenstedt, 1990).

\section{Numerical analysis}

The results of numerical analysis based on 115 growth and physiological characteristics are presented by a dendrogram (Fig. 1). Seventeen strains, including novel isolates and $N$. dassonvillei VKM Ac- $797^{\mathrm{T}}, N$. dassonvillei VKM Ac-773, N. dassonvillei VKM Ac836 and $N$. dassonvillei VKM Ac- $1882^{\mathrm{T}}$, formed a common phenetic cluster at $S_{\mathrm{J}}=66 \%$. While most of

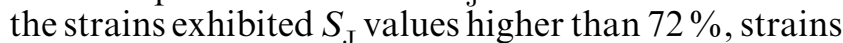
VKM Ac-1453 and VKM Ac- $1882^{\mathrm{T}}$ branched separately. Members of other species included in the numerical analysis, $N$. alba and N. listeri, isolate VKM Ac- $1457^{\mathrm{T}}$ and strain ' $N$. trehalosi' VKM Ac-942 ${ }^{\mathrm{T}}$, defined individual lineages which were separated from each other and from the cluster of $N$. dassonvillei at $S_{\mathrm{J}}$ levels of $53-63 \%$.

\section{S rDNA sequence analysis}

The almost complete 16S rDNA sequences of strain Nocardiopsis sp. VKM Ac- $1457^{\mathrm{T}}$ and ' $N$. trehalosi' VKM Ac- $942^{\mathrm{T}}$ which we determined contained 1452 and 1474 nucleotides, respectively. Comparison of the sequences of these strains with reference sequences 


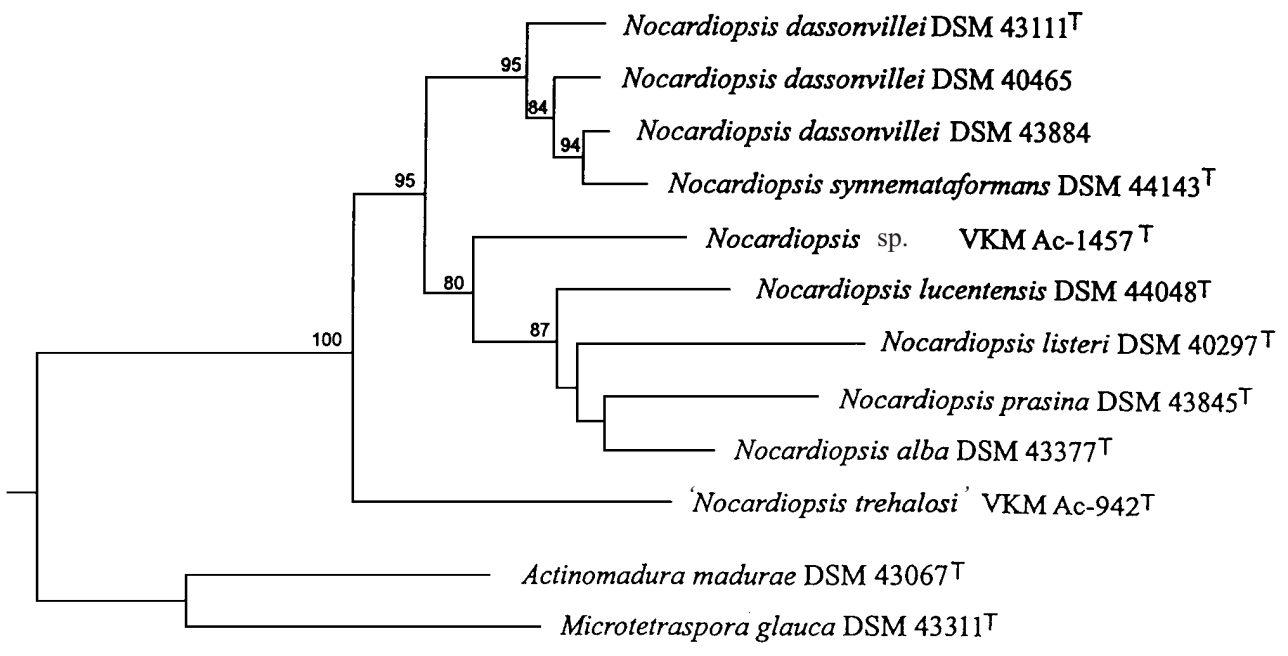

K nuk 0.01

Fig. 2. Phylogenetic tree showing the position of Nocardiopsis strains based on $16 \mathrm{~S}$ rDNA analysis. Sequences of the genus Streptosporangium served as an outgroup. Numbers within the dendrogram indicate the percentages of occurrence of the branching order in 1000 bootstrapped trees. Bar, 1 nucleotide substitution per 100 nucleotides.

Table 3. DNA relatedness between tested Nocardiopsis strains

\begin{tabular}{|c|c|c|c|c|}
\hline \multirow[t]{2}{*}{ Name } & \multirow[t]{2}{*}{ Strain } & \multicolumn{3}{|c|}{ DNA relatedness $(\%)$} \\
\hline & & $\begin{array}{l}\text { N. dassonvillei } \\
\text { VKM Ac-797 }\end{array}$ & $\begin{array}{l}\text { N. dassonvillei } \\
\text { VKM Ac-1882 }\end{array}$ & $\begin{array}{l}\text { Nocardiopsis sp. } \\
\text { VKM Ac-1457 }\end{array}$ \\
\hline N. dassonvillei & VKM Ac- $797^{\mathrm{T}}$ & 100 & 72 & 29 \\
\hline N. dassonvillei & VKM Ac-773 & 92 & 64 & 22 \\
\hline N. dassonvillei & VKM Ac-836 & 83 & 80 & 30 \\
\hline Nocardiopsis sp. & VKM Ac-1485 & 89 & 75 & 26 \\
\hline Nocardiopsis sp. & VKM Ac-1459 & 82 & 65 & 28 \\
\hline Nocardiopsis sp. & VKM Ac-1498 & 78 & 74 & 23 \\
\hline Nocardiopsis sp. & VKM Ac-1751 & 89 & 73 & 26 \\
\hline Nocardiopsis sp. & VKM Ac-1453 & 74 & 57 & 24 \\
\hline N. dassonvillei & VKM Ac- $1882^{\mathrm{T}}$ & 71 & 100 & 39 \\
\hline N. alba & VKM Ac- $1883^{\mathrm{T}}$ & 29 & 25 & 21 \\
\hline N. lucentensis & VKM Ac- $1963^{\mathrm{T}}$ & 37 & 21 & 29 \\
\hline N. listeri & VKM Ac- $1881^{\mathrm{T}}$ & 31 & 37 & 22 \\
\hline N. prasina & VKM Ac- $1880^{T}$ & 32 & 33 & 26 \\
\hline Nocardiopsis sp. & VKM Ac- $1457^{\mathrm{T}}$ & 31 & 36 & 100 \\
\hline 'N. trehalosi' & VKM Ac-942 & 16 & 17 & 22 \\
\hline
\end{tabular}

indicates that both organisms are members of the Nocardiopsis phylogenetic cluster, supported by $100 \%$ of the bootstrapped trees (Fig. 2). Within this cluster, ' $N$. trehalosi' VKM Ac-942 $2^{\mathrm{T}}$ was determined to be phylogenetically isolated, defining the deepest branch within the genus Nocardiopsis. The binary sequence similarity of this strain with other species of the genus Nocardiopsis was found to be from $96 \cdot 2$ to $97.6 \%$, demonstrating that ' $N$. trehalosi' belongs to a new species. Isolate VKM Ac- $1457^{\mathrm{T}}$ formed a distinct lineage with an $80 \%$ bootstrap replication value attached to the cluster of $N$. alba, N. prasina, $N$. listeri and $N$. lucentensis with a sequence similarity between 98.0 and $98.3 \%$. These values of $16 \mathrm{~S}$ rDNA sequence similarity are approximately the same or less than the similarity values between other closely related species of this genus. The data obtained indicate that strain VKM Ac- $1457^{\mathrm{T}}$ most likely belongs to a new species. However, high degrees of $16 \mathrm{~S}$ rDNA sequence similarity (97\% and higher) were demonstrated to be of 
Table 4. Differentiating characteristics of Nocardiopsis species and subspecies

,+ All strains are positive; $d+$, most of the strains are positive; - , all strains are negative; $d-$, most of the strains are negative; ND, no data.

\begin{tabular}{|c|c|c|c|c|c|c|c|c|c|c|}
\hline Characteristic & $\begin{array}{l}\text { N. tropica } \\
\text { sp. nov. }\end{array}$ & $\begin{array}{l}N . \text { trehalosi } \\
\text { sp. nov. }\end{array}$ & $\begin{array}{l}N . \text { dassonvillei } \\
\text { subsp. dassonvillei }\end{array}$ & $\begin{array}{l}\text { N. dassonvillei } \\
\text { subsp. albirubida subsp. nov. }\end{array}$ & N. alba & N. listeri & $N \cdot$ prasina & N. lucentensis & N. halophila* & N. synnemataformans $\dagger$ \\
\hline Aerial mycelium & + & + & + & + & $\mathrm{d}+\mathrm{t}$ & - & + & + & + & + \\
\hline Synnemata & - & - & - & - & - & - & - & - & - & + \\
\hline \multicolumn{11}{|l|}{ Utilization of: } \\
\hline L-Arabinose & + & + & + & + & - & + & + & - & + & - \\
\hline Inositol & - & - & - & - & - & + & - & + & + & - \\
\hline Melibiose & + & + & - & - & - & + & - & - & ND & ND \\
\hline L-Rhamnose & + & + & + & + & - & + & - & + & + & + \\
\hline D-Xylose & + & + & + & + & - & + & + & - & + & + \\
\hline \multicolumn{11}{|l|}{ Acid from: } \\
\hline Adonitol & - & - & $\mathrm{d}-$ & - & - & + & - & - & $\mathrm{ND}$ & ND \\
\hline L-Arabinose & + & + & $d+t$ & + & - & + & + & - & + & ND \\
\hline Galactose & + & - & $d+$ & + & - & + & - & - & - & ND \\
\hline Glycerol & + & + & $d+t$ & + & + & - & + & + & ND & ND \\
\hline Inositol & - & - & $\mathrm{d}-$ & - & - & - & - & + & + & ND \\
\hline D-Lactose & - & + & - & - & - & + & - & - & - & ND \\
\hline Mannitol & + & + & + & + & + & - & + & + & + & ND \\
\hline D-Mannose & + & + & d- & + & - & - & - & + & - & ND \\
\hline Melibiose & + & - & - & - & - & + & - & - & ND & ND \\
\hline L-Rhamnose & + & - & + & + & - & + & - & + & + & ND \\
\hline Sucrose & + & - & $d+$ & - & + & - & + & + & - & ND \\
\hline D-Xylose & - & + & $d+$ & + & - & + & - & - & + & ND \\
\hline \multicolumn{11}{|l|}{ Decarboxylation of: } \\
\hline Lactate & + & + & + & + & + & + & + & - & ND & - \\
\hline Malonate & + & + & + & + & + & - & - & + & ND & ND \\
\hline Oxalate & + & - & $d+$ & + & - & - & + & - & ND & ND \\
\hline Propionate & + & + & + & - & + & + & + & + & ND & ND \\
\hline \multicolumn{11}{|l|}{ Decomposition of: } \\
\hline Casein & - & + & + & + & + & + & + & + & + & + \\
\hline Tyrosine & - & - & $d+\hbar$ & + & + & + & + & + & - & + \\
\hline Tween 80 & + & + & $\mathrm{d}-$ & - & + & - & - & - & + & ND \\
\hline Tween 85 & + & - & $d+$ & + & + & - & - & - & ND & ND \\
\hline Nitrate reductase & - & - & $\mathrm{d}-$ & + & $\mathrm{d}-$ & + & - & + & ND & + \\
\hline Urease & + & + & $\mathrm{d}-$ & - & $\mathrm{d}+\hbar$ & - & - & - & + & + \\
\hline \multicolumn{11}{|l|}{ Growth at: } \\
\hline $10 \% \mathrm{NaCl}$ & + & - & $d+$ & + & $d-$ & - & + & + & + & + \\
\hline $20 \% \mathrm{NaCl}$ & - & - & - & - & - & - & - & - & + & ND \\
\hline $10^{\circ} \mathrm{C}$ & - & - & $\mathrm{d}-$ & - & - & + & - & + & ND & - \\
\hline $42{ }^{\circ} \mathrm{C}$ & - & + & $d+\hbar$ & + & $d+t$ & - & + & - & - & - \\
\hline $45^{\circ} \mathrm{C}$ & - & + & - & - & - & - & - & - & - & - \\
\hline Major menaquinone & s $10 / 6,10 / 8$ & $10 / 4,10 / 6$ & $10 / 4,10 / 6 \S$ & $10 / 0$ & $\begin{array}{l}10 / 4 \\
10 / 6 \|\end{array}$ & $\begin{array}{l}10 / 0 \\
10 / 2 \|\end{array}$ & $\begin{array}{l}10 / 4 \\
10 / 6 \|\end{array}$ & $10 / 6,10 / 8$ & $10 / 6,10 / 8$ & $10 / 0,10 / 2$ \\
\hline
\end{tabular}

* Data from Al-Tai \& Ruan (1994).

$\dagger$ Data from Yassin et al. (1997).

† Type strain is positive.

$\S$ The following predominant menaquinones were found in some strains of this species: 10/4, 10/2;10/4, 9/4;10/2, 9/2;10/6, 9/6.

|l Data from Grund \& Kroppenstedt (1990).

- Data from Yassin et al. (1993).

limited usefulness for differentiating species, and DNA pairing studies need to be performed to recognize species affiliation (Stackebrandt \& Goebel, 1994).

\section{DNA-DNA reassociation study}

Fifteen strains, listed in Table 3, were hybridized against reference $\left[{ }^{3} \mathrm{H}\right] \mathrm{DNA}$ of $N$. dassonvillei VKM Ac- $797^{\mathrm{T}}, N$. dassonvillei VKM Ac- $1882^{\mathrm{T}}$ and VKM Ac- $1457^{\mathrm{T}}$. High DNA-DNA homologies (71-92\%) were obtained between $N$. dassonvillei VKM Ac- $797^{\mathrm{T}}$, other strains of this species and the new isolates, except for strain VKM Ac- $1457^{\mathrm{T}}$, indicating that these strains belong to the same species (Wayne et al., 1987). Strain
VKM Ac- $1457^{\mathrm{T}}$, which differed significantly from the $N$. dassonvillei cluster at the phenotypical level, exhibited only 21-39\% DNA-DNA homology with all other strains tested. These values are in agreement with the DNA-DNA similarity values between different species of Nocardiopsis obtained in this study and by Fischer et al. (1983) and Yassin et al. (1997).

\section{Taxonomic affiliation of the strains}

Nocardioform morphology, chemotaxonomic characteristics and $16 \mathrm{~S}$ rDNA sequence analysis show that all of the isolates listed in Table 1 and ' $N$. trehalosi' VKM Ac- $942^{\mathrm{T}}$ are members of the genus Nocardiopsis. As 
seen from the distinct phylogenetic positions of $\mathrm{No}$ cardiopsis sp. VKM Ac- $1457^{\mathrm{T}}$ and ' $N$. trehalosi' VKM Ac- $942^{\mathrm{T}}$ within the genus Nocardiopsis (Fig. 2), and low DNA-DNA similarity values to the type strains of the genus (Table 3), both strains differ from each other and from other species of Nocardiopsis. The distinctness of these organisms is also seen by numerical analysis based on 115 growth and physiological characteristics and by cell wall teichoic acid composition. The polymers 1,5-poly(ribitol phosphate) with side chains glycerol phosphate oligomers (Streshinskaya et al., 1996) and 1,3-poly(glycerol phosphate) with $\beta$-glucosyl residues (Streshinskaya et al., 1998) determined in strains Nocardiopsis sp. VKM Ac- $1457^{\mathrm{T}}$ and ' $N$. trehalosi' VKM Ac-942 ${ }^{\mathrm{T}}$, respectively, have not been found in other species of this genus (Shashkov et al., 1997; Tul'skaya et al., 1993, 1995a, b). All above data demonstrate that the strains under discussion are representatives of two new species of the genus Nocardiopsis. We propose the name Nocardiopsis tropica for strain VKM Ac- $1457^{\mathrm{T}}$, isolated from the rhizosphere of Casuarina sp. in a tropical region (Seychelles), and the original name Nocardiopsis trehalosi (Dolak et al., 1981) for strain VKM Ac-942 ${ }^{\mathrm{T}}$. These species can be distinguished from other $\mathrm{No}$ cardiopsis spp. by the characteristics set forth in Table 4 and some structural characteristics of their cell wall teichoic acids (Streshinskaya et al., 1996, 1998). The descriptions of the new species are given below.

The majority of the strains investigated were identified as $N$. dassonvillei, based on numerical analysis (Fig. 1) and the high levels of DNA-DNA hybridization between the isolates and the reference strains. Strain VKM Ac- $1882^{\mathrm{T}}$ was separated from other $N$. dassonvillei strains by the major menaquinone (MK-10), growth and physiological characteristics (Fig. 1; Table 4), and cell wall teichoic acid composition (Shashkov et al., 1997). In contrast to other strains of $N$. dassonville $i$ with the structurally identical polymers [a core represented by alternating units of poly(glycerol phosphate) and poly(glycosylglycerol phosphate) chains and the glycosyl substituents] (Tul'skaya et al., 1993, 1995b; Akimov et al., 1994), strain VKM Ac$1882^{\mathrm{T}}$ has an additional $O$-succinyl substituent in most glycosyl residues. However, the DNA-DNA similarity values between VKM Ac-1882 $2^{\mathrm{T}}$ and strains of $N$. dassonvillei are only slightly lower than those obtained with the type strain VKM Ac-797 $7^{\mathrm{T}}$ (Table 3). In our opinion, the genomic and phenetic differences do not lend sufficient support to describe a new species, but they are significant enough to consider strain VKM Ac- $1882^{\mathrm{T}}$ as a separate subspecies. We propose the name Nocardiopsis dassonvillei subsp. albirubida, taking into account the taxonomic history of this strain (Kudrina, 1957; Grund \& Kroppenstedt, 1990).

\section{Description of Nocardiopsis tropica sp. nov.}

Nocardiopsis tropica (tro' pi.ca. M. L. adj. tropica referring to the tropical region where the type strain was isolated).
Aerobic, oxidase- and catalase-positive nocardioform actinomycete. Usually the aerial mycelium is white; however, it has a cream colour on Czapek's agar. Substrate mycelium is colourless to olive-yellow or red-orange on the different media tested. Soluble pigments are yellow-orange to yellow on oatmeal agar or glycerol-nitrate agar. Melanin is not produced on peptone-yeast extract-iron agar (ISP 6). Aerial hyphae are long and zig-zag shaped at the beginning of sporulation, fragmenting into elongated spore-like structures which subsequently subdivide into short rod-shaped spores of irregular size. Spore surface is smooth. Long branched substrate hyphae fragment into non-motile elements. L-Arabinose, D-fructose, Dglucose, D-galactose, glycerol, melibiose, maltose, mannitol, D-mannose, L-rhamnose, sucrose and Dxylose are used as sole carbon sources for growth; adonitol, dulcitol, i-inositol, lactose, D-ribose and Dsorbose are not. Acids are produced from L-arabinose, D-fructose, D-galactose, D-glucose, glycerol, maltose, D-mannitol, melibiose, L-rhamnose and sucrose, but not from adonitol, dulcitol, i-inositol, lactose, Dribose, sorbose or D-xylose. An alkaline reaction is observed with citrate, formate, fumarate, lactate, malate, malonate, oxalate, propionate, pyruvate, sebacate, succinate and tartrate, but no alkaline reaction occurs with acetate, aconitate, benzoate or salicylate. Xanthine, hypoxanthine, calcium oxalate crystals, urea, Tween 40, Tween 60, Tween 80 and Tween 85 are decomposed; casein and tyrosine are not. Nitrates are not reduced to nitrites. Growth occurs on media supplemented with $10 \%$ (w/v) $\mathrm{NaCl}, 1.5 \%$ (v/v) butanol, $2 \cdot 5 \%(\mathrm{v} / \mathrm{v})$ methanol and $3 \%(\mathrm{v} / \mathrm{v})$ ethanol, but no growth occurs at $12 \%(\mathrm{w} / \mathrm{v}) \mathrm{NaCl}$ and $50 \mathrm{mg}$ lysozyme $\mathrm{ml}^{-1}$. Growth occurs at $37^{\circ} \mathrm{C}$ but not at $10{ }^{\circ} \mathrm{C}$ and $42{ }^{\circ} \mathrm{C}$; optimum growth is at $28-30{ }^{\circ} \mathrm{C}$. The major menaquinones are MK-10 $\left(\mathrm{H}_{6}, \mathrm{H}_{8}\right)$. Cell wall teichoic acid contains heterogeneous 1,5-poly(ribitol phosphate) chains with lateral glycerol phosphate oligomers. The type strain is VKM Ac- $1457^{\mathrm{T}}$. Isolated from soil in the rhizosphere of Casuarina sp. (Seychelles).

\section{Description of Nocardiopsis trehalosi sp. nov., nom. rev.}

Nocardiopsis trehalosi (tre.ha.lo'si. M.L. adj. trehalosi referring to 3-trehalosamine, an aminoglycoside antibiotic that is produced by the type strain of this species).

Aerobic, oxidase- and catalase-positive nocardioform actinomycete. The aerial mycelium is white to cream or yellowish grey. The colour of the substrate mycelium ranges from pale olive-brownish to pale orangeyellow. A light yellow-brownish or light orange-yellow soluble pigment is produced on some media. No melanin is observed on peptone-yeast extract-iron agar (ISP 6). Aerial hyphae are zig-zag or twisted-ribbonlike at the beginning of sporulation; spores are irregularly sized (mostly elongated) and have a smooth surface. Long branched substrate hyphae fragment 
into non-motile elements. L-Arabinose, D-fructose, D-galactose, D-glucose, glycerol, lactose, maltose, D-mannitol, D-mannose, L-rhamnose and D-xylose are used for growth as sole carbon sources, but not adonitol, i-inositol, melibiose, D-sorbitol or sucrose. Acids are produced from L-arabinose, D-fructose, glycerol, lactose, maltose, D-mannitol, D-mannose and D-xylose, but not from adonitol, D-galactose, i-inositol, melibiose, L-rhamnose, D-sorbose or sucrose. Acetate, citrate, formate, fumarate, lactate, malate, malonate, pyruvate, propionate, sebacate, succinate and tartrate are utilized; no alkaline reaction occurs with aconitate, benzoate, salicylate and oxalate. Casein, calcium oxalate crystals, hypoxanthine, xanthine, Tween 80 and urea are decomposed, but not tyrosine, Tween 40 , Tween 60 and Tween 85. Decomposition of aesculin is variable. Nitrates are not reduced to nitrites. The strain is resistant to $50 \mathrm{mg}$ lysozyme $\mathrm{ml}^{-1}$. Growth occurs on media supplemented with $5 \%(\mathrm{w} / \mathrm{v}) \mathrm{NaCl}$, $2.5 \%(\mathrm{v} / \mathrm{v})$ methanol and $3 \%(\mathrm{v} / \mathrm{v})$ ethanol, but no growth occurs at $10 \%(\mathrm{w} / \mathrm{v}) \mathrm{NaCl}$ and $0.5 \%(\mathrm{v} / \mathrm{v})$ butanol. Growth temperature ranges between 18 and $45^{\circ} \mathrm{C}$; no growth occurs at $10{ }^{\circ} \mathrm{C}$. Optimum growth is at $28-37^{\circ} \mathrm{C}$. The major menaquinones are $\mathrm{MK}-10\left(\mathrm{H}_{4}\right.$, $\left.\mathrm{H}_{6}\right)$. Cell wall teichoic acid of poly(glycerol phosphate) with $\beta$-glucosyl residues. Produces 3-trehalosamine. The type strain is VKM Ac-942 ${ }^{\mathrm{T}}$ (NRRL $12026^{\mathrm{T}}=$ JCM $3357^{\mathrm{T}}=$ IFO $14201^{\mathrm{T}}$ ). The description above is based on the data of Dolak et al. $(1980,1981)$ and our study.

\section{Description of Nocardiopsis dassonvillei subsp. albirubida subsp. nov., comb. nov.}

The description of this subspecies is as presented by Grund \& Kroppenstedt (1990). The characteristics which differentiate this subspecies from other strains of $N$. dassonvillei are the following: major menaquinone MK-10; cell wall glycerol teichoic acid of mixed structure containing an additional $O$-succinyl residue; production of nitrite from nitrate; growth in $1.5 \%(\mathrm{v} / \mathrm{v})$ butanol; use of lactose and melezitose as a sole carbon source; utilization of quinate; production of acid from D-mannose. The type strain is VKM Ac-1882 ${ }^{\mathrm{T}}\left(=\mathrm{DSM} 40465^{\mathrm{T}}=\right.$ ATCC $23612^{\mathrm{T}}=$ ISP $5465^{\mathrm{T}}=\mathrm{JCM} 4717^{\mathrm{T}}=$ IFO $13392^{\mathrm{T}}$ ).

\section{ACKNOWLEDGEMENTS}

This work was financially supported by INTAS grant 961571, Russian Foundation for Basic Research grant 97-0449087, and NSF grants INT 9315089 and DEB 9120006 to the Center for Microbial Ecology.

\section{REFERENCES}

Abyzov, S. S., Philipova, S. N. \& Kuznetsov, V. D. (1983). Nocardiopsis antarcticus, a new species of actinomycetes, isolated from the ice sheet of the central antarctic glacier. Izv Akad Nauk SSSR Ser Biol 4, 559-568.

Akimov, V. N., Taran, V. V., Evtushenko, L. I., Naumova, I. B. \& Kalakoutskii, L. V. (1994). Grouping of Nocardiopsis strains on the basis of DNA relatedness. In Theses of the 9th International Symposium on the Biology of Actinomycetes, p. 242. Moscow: VINITI.

Al-Tai, A. M. \& Ruan, J.-S. (1994). Nocardiopsis halophila sp. nov., a new halophilic actinomycete isolated from soil. Int $J$ Syst Bacteriol 44, 474-478.

Becker, B., Lechevalier, M. P., Gordon, R. E. \& Lechevalier, H. A. (1964). Rapid differentiation between Nocardia and Streptomyces by paper chromatography of whole cell hydrolysates. Appl Microbiol 12, 421-423.

Blom, J., Roelofsen, W. \& Akkermans, A. D. L. (1980). Growth of Frankia AvcI1 on media containing Tween 80 as C-source. FEMS Microbiol Lett 9, 131-135.

Bradley, S. G., Brownell, G. H. \& Clark, J. (1973). Genetic homologies among nocardia and other actinomycetes. Can $J$ Microbiol 19, 1007-1014.

Collins, M. D., Pirouz, T., Goodfellow, M. \& Minnikin, D. E. (1977). Distribution of menaquinones in actinomycetes and corynebacteria. J Gen Microbiol 100, 221-230.

DeSoete, G. (1983). A least squares algorithm for fitting additive trees to proximity data. Psychometrika 48, 621-626.

Dolak, L. A., Castle, T. M. \& Laborde, L. A. (1980). 3-Trehalosamine, a new disaccharide antibiotic. $J$ Antibiot 33, 690-694.

Dolak, L. A., Castle, T. M. \& Laborde, L. A. (1981). Biologically pure culture of Nocardiopsis trehalosei sp. nov. US Patent 4306028.

Erikson, D. (1935). The pathogenic aerobic organisms of the actinomycetes group. Med Res Counc Spec Rep 203, 1-61.

Felsenstein, J. (1985). Confidence limits on phylogenies: an approach using the bootstrap. Evolution 39, 783-789.

Fischer, A., Kroppenstedt, R. M. \& Stackebrandt, E. (1983). Molecular-genetic and chemotaxonomic studies on Actinomadura and Nocardiopsis. J Gen Microbiol 129, 3433-3446.

Gause, G. F., Preobrazhenskaya, T. P., Sveshnokova, G. V., Terekhova, L. P. \& Maksimova, T. S. (1983). A Guide for Determination of Actinomycetes. Moscow: Nauka.

Goodfellow, M., Stackebrandt, E. \& Kroppenstedt, R. M. (1988). Chemotaxonomy and actinomycete systematics. In Biology of Actinomycetes 88, pp. 233-238. Edited by Y. Okami, T. Beppu \& H. Ogawara. Tokyo: Japan Scientific Societies Press.

Gordon, R. E. (1967). The taxonomy of soil bacteria. In The Ecology of Soil Bacteria, pp. 239-321. Edited by T. R. G. Gray \& D. Parkinson. Liverpool: Liverpool University Press.

Gordon, R. E. \& Horan, A. S. (1968). Nocardia dassonvillei, a macroscopic replica of Streptomyces griseus. J Gen Microbiol 50, 235-240.

Gordon, R. E. \& Mihm, J. M. (1957). A comparative study of some strains received as nocardiae. $J$ Bacteriol 73, 15-27.

Grund, E. \& Kroppenstedt, R. M. (1990). Chemotaxonomy and numerical taxonomy of the genus Nocardiopsis Meyer 1976. Int $J$ Syst Bacteriol 40, 5-11.

Hasegawa, T., Takizawa, M. \& Tanida, S. (1983). A rapid analysis for chemical grouping of aerobic actinomycetes. J Gen Appl Microbiol 29, 319-322.

Jukes, T. H. \& Cantor, C. R. (1969). Evolution of protein molecules. In Mammalian Protein Metabolism, pp. 21-132. Edited by H. N. Munro. New York: Academic Press.

Kroppenstedt, R. M. (1985). Fatty acid and menaquinone analysis of actinomycetes and related organisms. Soc Appl Bacteriol Tech Ser 20, 173-197. 
Kroppenstedt, R. M. (1992). The genus Nocardiopsis. In The Prokaryotes, 2nd edn, pp. 1139-1156. Edited by A. Balows, H. G. Trüper, M. Dworkin, W. Harder \& K.-H. Schleifer. New York: Springer.

Kudrina, E. S. (1957). Characteristic of actinomycetes-antagonists of the Albosporeus series. In Problems of Classification of Actinomycetes-Antagonists, pp. 109-111. Edited by G. F. Gauze, T. P. Preobrazhenskaya, E. S. Kudrina, N. O. Blinov, I. D. Ryabova \& M. A. Sveshnikova. Moscow: Government Publishing House of Medical Literature.

Lechevalier, H. G. \& Lechevalier, M. P. (1970). A critical evaluation of the genera of aerobic actinomycetes. In The Actinomycetales, pp. 393-405. Edited by H. Prauser. Jena: Gustav Fischer.

Lechevalier, M. P., DeBierve, C. \& Lechevalier, H. A. (1977). Chemotaxonomy of aerobic actinomycetes: phospholipid composition. Biochem Syst Ecol 5, 249-260.

Maidak, B. L., Olsen, G. J., Larsen, N., Overbeck, R., McCaughey, M. J. \& Woese, C. R. (1997). The RDP (Ribosomal Database Project). Nucleic Acids Res 25, 109-111.

Meyer, J. (1976). Nocardiopsis, a new genus of the order Actinomycetales. Int J Syst Bacteriol 26, 487-493.

Meyer, S. A. \& Schleifer, K. H. (1978). Deoxyribonucleic acid reassociation in the classification of coagulase-positive staphylococci. Arch Microbiol 117, 183-188.

Miller, L. T. (1982). Single derivatization method for routine analysis of bacterial whole-cell, fatty acids methyl esters, including hydroxy acids. J Clin Microbiol 16, 584-586.

Minnikin, D. E., Alshamaony, L. \& Goodfellow, M. (1975). Differentiation of Mycobacterium, Nocardia and related taxa by thin-layer chromatographic analysis of whole-cell methanolysates. J Gen Microbiol 88, 200-204.

Minnikin, D. E., O'Donnell, A. G., Goodfellow, M., Alderson, G., Athalye, M., Schaal, A. \& Parlett, J. H. (1984). An integrated procedure for the extraction of bacterial isoprenoid quinones and polar lipids. J Microb Methods 2, 233-241.

Miyashita, M., Mikami, Y. \& Arai, T. (1984). Alkalophilic actinomycete, Nocardiopsis dassonvillei subsp. prasina subsp. nov. isolated from soil. Int J Syst Bacteriol 34, 405-409.

Naumova, I. B., Kuznetsov, V. D., Kudrina, K. B. \& Bezzubenkova, A. B. (1980). The occurrence of teichoic acids in Streptomyces. Arch Microbiol 126, 71-75.

Ozerskaya, S. M. \& Vasilenko, A. N. (1992). Package for cluster analysis on IBM PC computer. Binary 4, 33-34.

Rainey, F. A., Ward-Rainey, N., Kroppenstedt, R. M. \& Stackebrandt, E. (1996). The genus Nocardiopsis represents a phylogenetically coherent taxon and a distinct actinomycete lineage: proposal of Nocardiopsaceae fam. nov. Int $J$ Syst Bacteriol 46, 1088-1092.

Shashkov, A. S., Streshinskaya, G. M., Kozlova, Yu. I., Potekhina, N. V., Evtushenko, L. I., Taran, V. V. \& Naumova, I. B. (1997). Structure of teichoic acid from cell walls of Nocardiopsis alborubida. Biochemistry (Mosc) 62, 1135-1139.

Shirling, E. B. \& Gottlieb, D. (1966). Methods for characterization of Streptomyces species. Int J Syst Bacteriol 16, 313-340.

Stackebrandt, E. \& Goebel, B. M. (1994). Taxonomic note: a place for DNA-DNA reassociation and $16 \mathrm{~S}$ rRNA sequence analysis in the present species definition in bacteriology. Int $J$ Syst Bacteriol 44, 846-849.
Stackebrandt, E., Wunner-Fussl, V., Fowler, V. J. \& Schleifer, K.-H. (1981). Deoxyribonucleic acid homologies and ribosomal ribonucleic acid similarities among sporeforming members of the order Actinomycetales. Int J Syst Bacteriol 31, 420-431.

Stackebrandt, E., Rainey, F. A. \& Ward-Rainey, N. L. (1997). Proposal for a new hierarchic classification system, Actinobacteria classis nov. Int $J$ Syst Bacteriol 47, 479-491.

Stevenson, I. L. (1967). Utilization of aromatic hydrocarbons by Arthrobacter spp. Can J Microbiol 13, 205-211.

Streshinskaya, G. M., Kozlova, Yu. I., Evtushenko, L. I., Taran, V. V., Shashkov, A. S. \& Naumova, I. B. (1996). Cell wall teichoic acid of Nocardiopsis sp. VKM Ac-1457. Biochemistry (Mosc) 61, 285-288.

Streshinskaya, G. M., Tul'skaya, E. M., Shashkov, A. S., Evtushenko, L. I., Taran, V. V. \& Naumova, I. B. (1998). Teichoic acids of the cell wall of Nocardiopsis listeri, Nocardiopsis lucentensis, and Nocardiopsis tregalosei. Biochemistry (Mosc) 63, 230-234.

Tul'skaya, E. M., Streshinskaya, G. M., Naumova, I. B., Shashkov, A. S. \& Terekhova, L. P. (1993). A new structural type of teichoic acid and some chemotaxonomic criteria of two species $\mathrm{No}$ cardiopsis dassonvillei and Nocardiopsis antarcticus. Arch Microbiol 160, 299-305.

Tul'skaya, E. M., Shashkov, A. S., Evtushenko, L. I., Taran, V. V. \& Naumova, I. B. (1995a). Novel cell-wall teichoic acid from Nocardiopsis albus subsp. albus as a species-specific marker. Microbiology 141, 1851-1856.

Tul'skaya, E. M., Shashkov, A. S., Evtushenko, L. I., Taran, V. V. \& Naumova, I. B. (1995b). New teichoic acids in some Nocardiopsis species. In The Biosynthesis and Degradation of Microbial Polymers, p. 53. Edited by I. Kulaev. Pushchino: Pushchino Research Centre.

Wayne, L. G., Brenner, D. J., Colwell, R. R. \& 9 other authors (1987). International Committee on Systematic Bacteriology. Report of the ad hoc committee on reconciliation of approaches to bacterial systematics. Int J Syst Bacteriol 37, 463-464.

Weisburg, W. G., Barns, S. M., Pelletier, D. A. \& Lane, D. J. (1991). $16 \mathrm{~S}$ ribosomal DNA amplification for phylogenetic study. J Bacteriol 173, 697-703.

Williams, S. T., Goodfellow, M., Alderson, G., Wellington, E. M. H., Sneath, P. H. A. \& Sackin, M. J. (1983). Numerical classification of Streptomyces and related taxa. J Gen Microbiol 129, 1743-1813.

Yassin, A. F., Galinski, E. A., Wohlfarth, A., Jahnke, K.-D., Schaal, K. P. \& Trüper, H. G. (1993). A new actinomycete species, Nocardiopsis lucentensis sp. nov. Int $J$ Syst Bacteriol 43, 266-271.

Yassin, A. F., Rainey, F. A., Burhardt, J., Gierth, D., Ungerechts, J., Lux, I., Seifert, P., Bal, C. \& Schaal, K. P. (1997). Description of Nocardiopsis synnemataformans sp. nov., elevation of Nocardiopsis alba subsp. prasina to Nocardiopsis prasina comb. nov., and designation of Nocardiopsis antarctica and Nocardiopsis alborubida as later subjective synonyms of $\mathrm{No}$ cardiopsis dassonvillei. Int J Syst Bacteriol 47, 983-988.

Zhou, J., Davey, M. E., Figueras, J. B., Rivkina, E., Gilichinskii, D. \& Tiedje, J. M. (1997). Phylogenetic diversity of a bacterial community determined from Siberian tundra soil DNA. Microbiology 143, 3913-3919. 